\title{
PEMANFAATAN DIGITAL LIBRARY LET'S READ SEBAGAI MATERI BAHAN AJAR BAHASA INGGRIS UNTUK READING AND SPEAKING
}

\author{
${ }^{1}$ Siti Maria Ulfa, ${ }^{2}$ Hendra Sudarso \\ ${ }^{1}$ Prodi Pendidikan Bahasa Inggris, STKIP PGRI Bangkalan, J1 Soekarno Hatta No. 52, \\ Bangkalan, Indonesia 69116 \\ Email Korespondensi: sitimariaulfa@stkippgri-bkl.ac.id
}

\begin{abstract}
The breakthrough in Information Communication Technology (ICT) has brought new opportunities to restructure language learning. At present, ICT has opened new avenues and brought new challenges for language learners and also teachers. The responsibility of the learning task has shifted towards students and this has dramatically changed the role of the teacher. However, it should be noted that modern language teachers determine the quality of the learning process, not ICT itself. This paper tries to highlight the potential of ICT as a powerful tool for teaching foreign languages and the effect of this technology on second language learning. The community service program emphasizes the use of the Lets Read link as a forum to find teaching materials for Excellent Course teachers. Along with the development of technology as it is today, teachers must also be more flexible in finding teaching materials for their students, especially in learning English. Therefore, it is necessary for teachers to know useful links that can be used in learning in their class.
\end{abstract}

Keywords: Language Learning, ICT, Let's Read Application

\begin{abstract}
Abstrak
Terobosan Teknologi Komunikasi Informasi (TIK) telah membawa peluang baru untuk merestrukturisasi pengaturan pembelajaran / pengajaran bahasa. Saat ini, TIK telah membuka jalan baru dan membawa tantangan baru bagi pembelajar bahasa dan juga guru. Tanggung jawab tugas belajar telah bergeser ke arah peserta didik dan ini telah secara dramatis mengubah peran guru. Namun, perlu dicatat bahwa guru bahasa modern menentukan kualitas proses pembelajaran, dan bukan TIK. Makalah ini mencoba untuk menyoroti potensi TIK sebagai alat yang kuat untuk pengajaran bahasa asing dan efek dari teknologi ini pada pembelajaran bahasa kedua. Program pengabdian masyarakat menekankan pada pemanfaatan link Lets Read sebagai wadah pencarian bahan ajar bagi guru-guru LKP Excellent Course. Seiring dengan berkembangnya teknologi seperti sekarang ini, guru juga harus lebih luwes dalam mencari bahan ajar untuk siswanya kususnya dalam pembelajaran Bahas Inggris. Maka dari itu, perlu bagi guru-guru mengetahui link yang bermanfaat yang dapat digunakan dalam pembelajaran dikelas mereka.

Kata kunci: Pembelajaran Bahasa, Telnologi Komunikasi dan Informasi,l Aplikasi Let's Read
\end{abstract}

\section{PENDAHULUAN}

Teknologi komunikasi dan informasi telah membawa kita khususnya dalam dunia pendidikan pada kesempatan yang baru untuk merekonstruksi kembali pembelajaran Bahasa Inggris. Pada zaman sekarang penggunaan teknologi komunikasi dan informasi telah membuka dan membawa proses pembelajaran kearah tantangan yang baru khususnya bagi guru dan murid. Masalah yang lain di era globlalisasi ini salah satunya adalah penguasaan teknologi informasi (TIK) oleh para bapak dan ibu guru. Tidak bisa dipungkiri bahwa masih banyak para pengajar-pengajar kita yang masih belum menguasai teknologi informasi. Padahal teknologi informasi sekarang ini jika dimanfaatkan dengan baik maka dapat membantu dan mempermudah tugas-tugas guru di 
dalam menjalankan tuganya. Bahkan untuk anak setingkat sekolah dasar (SD) sekarang ini hampir semuanya sudah memiliki handphone. Perkembangan teknologi memang tidak bisa dicegah, tapi masalah yang utama adalah bagaimana kita bisa memanfaatkan dan mengarahkan anak didik kita pada pemanfaatan yang lebih baik. Masalah guru dalam memanfaatkan TIK di dalam kegiatan pembelajaran. Kemampuan guru harus diberdayakan secara maksimal.

Pemanfaatan teknologi dan informasi jika digunakan secara tepat dapat membantu kegiatan belajar siswa dan guru di dalam kelas. Darmawan (2003) mengemukakan bahwa profesionalisme bukan sekadar pengetahuan teknologi dan manajemen tetapi lebih merupakan sikap, pengembangan profesionalisme lebih dari seorang teknisi bukan hanya memiliki keterampilan yang tinggi tetapi memiliki suatu tingkah laku yang dipersyaratkan. Menurut Soetjipto (2002), guru 1) dasar ilmu yang kuat sebagai pengejawantahan terhadap masyarakat teknologi dan masyarakat ilmu pengetahuan di era globalisasi, 2) penguasaan kiat-kiat profesi berdasarkan riset dan praksis pendidikan yaitu ilmu pendidikan sebagai ilmu praksis bukan hanya merupakan konsep- konsep belaka. Pendidikan merupakan proses yang terjadi di lapangan dan bersifat ilmiah, serta riset pendidikan hendaknya diarahkan pada praksis pendidikan masyarakat Indonesia, 3) pengembangan kemampuan profesional berkelanjutan, profesi guru merupakan profesi yang berkembang terus menerus dan berkesinambungan antara LPTK dengan praktek pendidikan. Pengembangan kemampuan guru dalam menguasai TIK juga sangat bergantung pada kemampuan hard skill dan soft skill yang dimiliki oleh guru. Soft skills merupakan keterampilan dan kecakapan hidup, baik untuk sendiri, berkelompok, atau bermasyarakat, serta dengan Sang Pencipta. Dengan mempunyai soft skills membuat keberadaan seseorang akan semakin terasa di tengah masyarakat. Keterampilan akan berkomunikasi, keterampilan emosional, keterampilan berbahasa, keterampilan berkelompok, memiliki etika dan moral, santun dan keterampilan spiritual. Soft skill yaitu semua sifat yang menyebabkan berfungsinya hard skills yang dimiliki. Soft skills dapat menentukan arah pemanfaatan hard skills. Jika seseorang memilikinya dengan baik, maka ilmu dan keterampilan yang dikuasainya dapat mendatangkan kesejahteraan dan kenyamanan bagi pemiliknya dan lingkungannya

Erat kaitannya dengan hal diatas, banyak sekali guru-guru yang sudah bisa sedikit banyak menguasai TIK tetapi sangat banyak pula dari mereka tidak peduli dengan materi yang seharusnya mereka berika. Mereka cenderung acuh terhadap materi yang up-to-date 
yang sebenarnya mereka bisa dapatkan melalui pemanfaatan ICT. Maka dari analisi situasi inilah, diperlukan sebuah kegiatan yang berkontribusi pada keberlangsungan pemanfaatan teknologi khusunya dikelas pembelajaran Bahasa Inggris. Salah satu cara yang dapat membantu guru dalam kaitannya dengan pemanfaatan bahan atau materi ajar. Penggunaan digital library dapat digunakan. dan ditambahkan oleh (Deni, 2013) dimana disampaikan bahwa Digital Library dapat menghemat ruangan dan tak terbatas oleh ruang dan waktu. Beberapa jenis digital library yang secara bebas dapat diakses adalah Let's Read. Selain itu Library Genesis dan Wiley Online Library termasuk salah satu contoh digital library yang sangat membantu pengajar dalam mencari bahan ajar untuk pembelajaran dikelas (Li, Jiao, Zhang, \& Xu, 2019)Dalam kedua jenis digital library tersebut bukan hanya dapat menemukan buku, tetapi juga jurnal-jurnal rujukan sesuai kebutuhan pengajar. Hal ini tentu saja menjadi hal yang sangat membantu. Berikut dapat dilihat tampilan penggunaan Digital Library Let's Read yang digunakan dalam kegiatan Pengabdian Kepada Masyarakat.

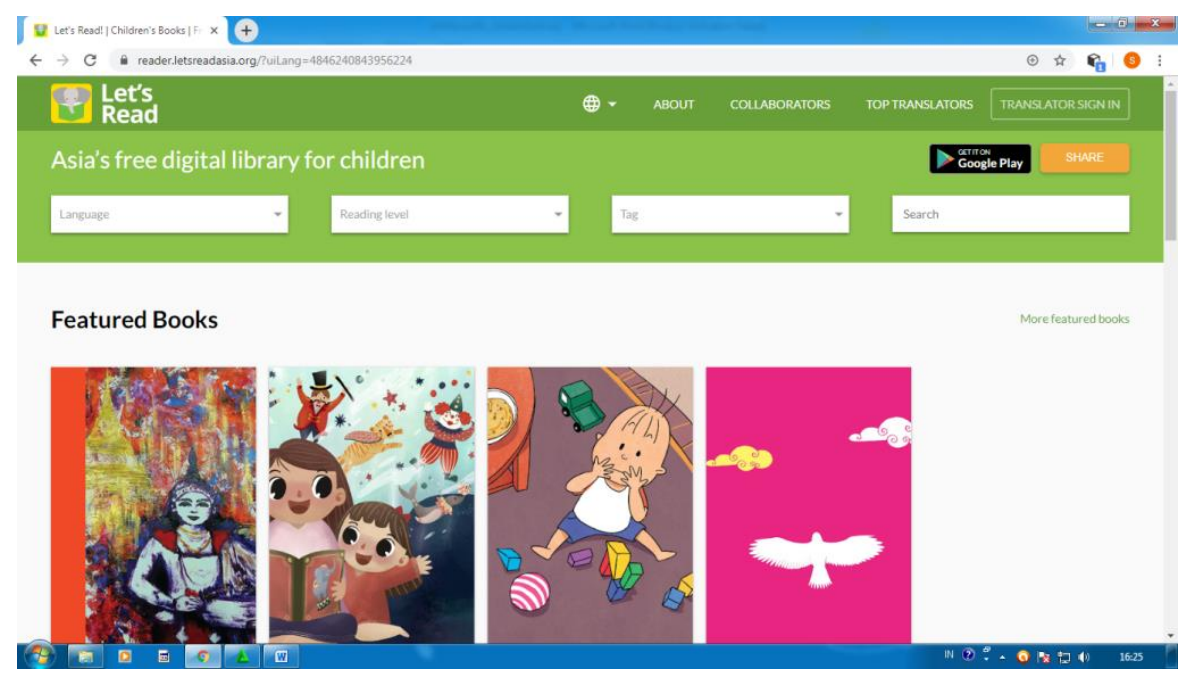

Gambar 1. Tampilan Let's Read yang dipakai 


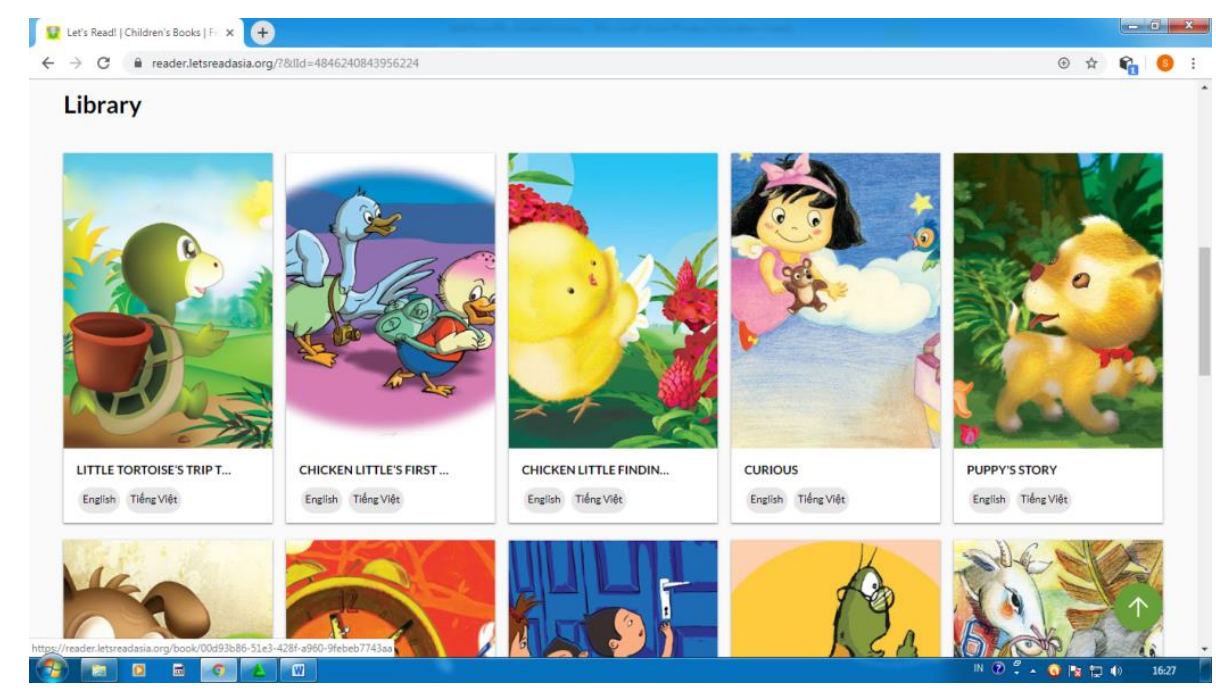

Gambar 2. Bahan bacaan yang dapat diunduh

\section{METODE}

Ada empat hal yang akan dipaparkan dalam metode ini, diantaranya adalan perencanaan, tindakan, evaluasi dan refleksi.

Perencanaan

Perencanaan dilakukan melalui diskusi dan komunikasi yang ditawarkan kepada mitra. Salah satu caranya adalah dengan menyusun jadwal pelatihan yang disesuaikan dengan jadwal mereka.

Tindakan

Rencana Kegiatan. Rencana kegiatan dalam program ini meliputi kegiatan pendampinga guru-guru dalam memanfaatkan teknologi khususnya link Lets' Read untuk mengajar Reading dan Speaking. Partisipasi mitra dalam hal ini sebagai tempat pelaksanaan kegiatan. Nantinya tidak menutup kemungkinan bagi guru-guru yang ada disekitar LKP Excellent Course untuk bergabung selama acara pendampingan dan penyuluhan berlangsung.

Evaluasi

Evaluasi akan dilakukan secara periodic setelah acara berlangsung. Hal tersebut dapat nantinya dilihat bagaimana guru-guru tersebut menindaklanjuti kegiatan pendampingan ini. Dengan nantinya dibuat grup WA, mereka akan secara kontinyu akan dicek dan ditanyakan perihal materi apa saja yang sudah diunduh dan dimanfaatkan 
dikelas mereka masing-masing. Hal ini tentu saja akan berkontribusi pada keberlanjutan program lainnya tapi sejenis. Mungkin akan dilanjutkan kepada perihal assessment, lebih tepatnya bagaimana membuat assessment berbasis E-Porfolio, dan kerjasama ini akan berlangsung terus bukan hanya dengan hal yang berkaitan dengan pelaksanaan pengabdian ini.

Refleksi

Refleksi dilakukan dengan melihat adanya hal yang harus diperbaiki yang erat kaitannya dengan penggunaan aplikasi Let's Read tersebut. Hal ini perlu dilakukan agar tujuan kegiatan ini tercapai.

\section{HASIL DAN PEMBAHASAN}

Pelaksanaan kegiatan ini dimaksudkan untuk memberikan informasi terkait penggunaan teknologi untuk membantu guru-guru les di LKP Excellent Course sebagai bahan tambahan dalam mengajar siswa mereka reading dan speaking dengan menggunakan konten-konten yang ada didalamnya.

Kaitannya dengan respon para pengajar terhadap adanya kegiatan ini sangatlah positif. Mereka menyampaikan bahwa mereka baru mengetahui adanya aplikasi ini yang sangat bermanfaat bagi anak didik les mereka. Murid-murid cenderung mendapatkan cerita yang biasanya ada seperti Malin Kundang, Cinderella dan lain lain yang dinilai sungguh sangat lalu. Maka dari itu adanya aktivitas ini diharapkan dapat memotivasi guru-guru untuk lebih kreatif lagi dalam menggunakan teknologi untuk mengajar Bahasa Inggris. Kemudian untuk memudahkan sistematika pelaporan kegiatan, maka gambargambar dibawah ini dapat dijadikan informasi terkait pelaksanaan kegiatan tersebut.

Dapat dilihat bahwa pelaksanaan kegiatan Pengabdian kepada Mastarakat ini dilakukan dengan proses sebagai berikut. Pertama adalah mengkondisikan para pengajar di LKP dengan menggunakan media seperti laptop dan lainnya.

Setelah itu, pengajar mulai dipaparkan aplikasi Let's Read seabagai wahana yang bisa digunakan dalam mengajar. Disini para pengajar dan dosen berkolaborasi dalam penentuan dan penggunaak aplikasi tersebut. Mereka saling berkomunikasi dan mencari jenis cerita apa saja yang dapat digunakan dikelas. Beberapa fitur juga digunakan dan dipertanyakan penggunaannya. Hal tersebut tentunya dilakukan dan disesuaikan dengan materi yang disampaikan kepada anak didik. 
Berikutnya adalah dilakukan simulasi mengajar dengan menggunakan aplikasi tersebut dan hal tersebut menjadi bahan evaluasi dan refleksi. Beberapa hal yang perlu mendapatkan perhatian adalah adanya keterbatasan koneksi internet yang sangat mendukung pembelajaran berlangsung ketika hal itu terpenuhi dengan baik. Kemudian hal yang lain adalah jenis cerita yang agak sedikit berbeda dengan cerita yang biasanya anak-anak terima dikelas, maka hal itu menjadi tantangan tersendiri untuk pengajar tuntaskan karena pengajar disini juga dituntu untuk dapt menggunakan ICT yang bisa menstimulasi peserta didik untuk mendukung strategi belajarnya (Ghasemi \& Hashemi, 2011). Hal-hal yang telah disebutkan diatas dapt dilihat melalui gambar-gambar dibawah ini.

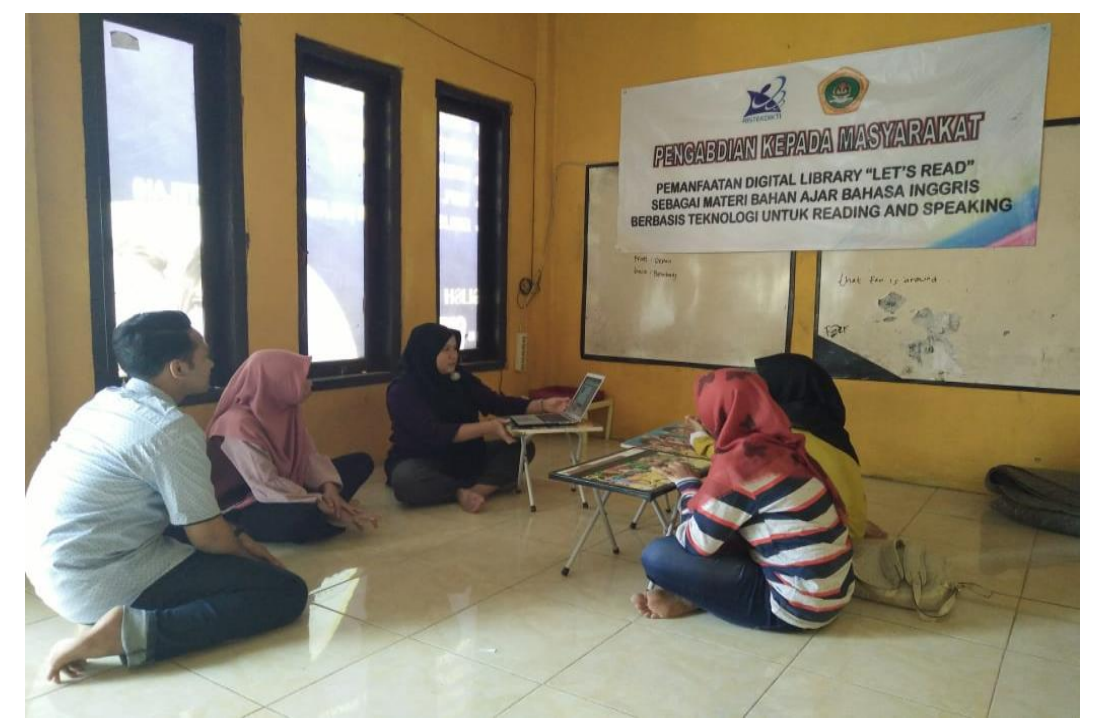

Gambar 3. Peneliti masih menjelaskan macam-macam cerita yang ada dalam Let's Read Application 


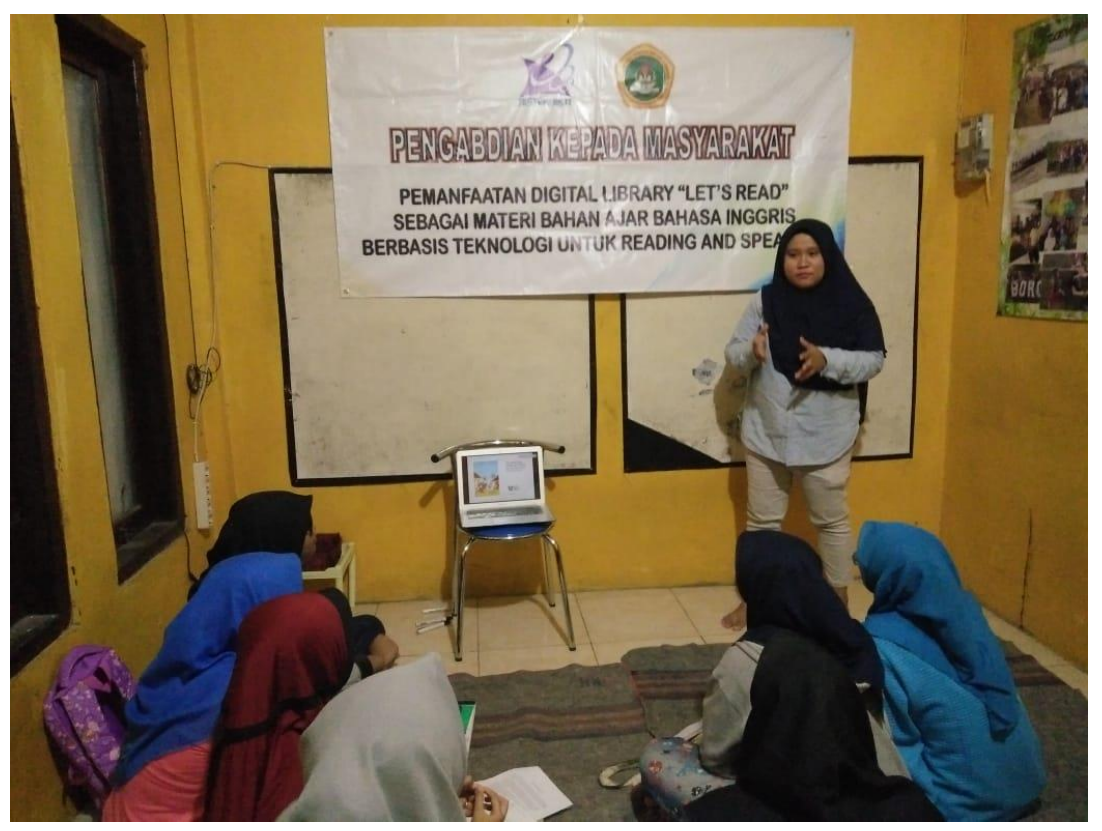

Gambar 4. Peneliti memberikan pengarahan pembuka sebelum aplikasi Let's Read digunakan

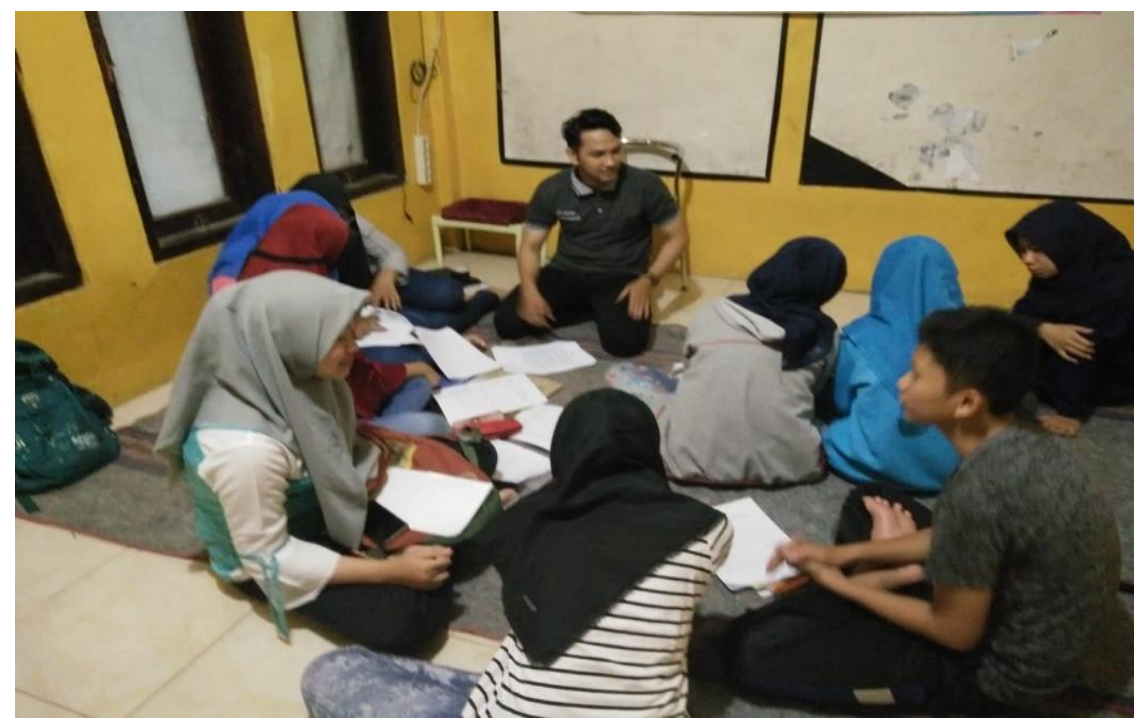

Gambar 5. Guru LKP Excellent Course mengajar dengan menggunakan aplikasi Let's Read 


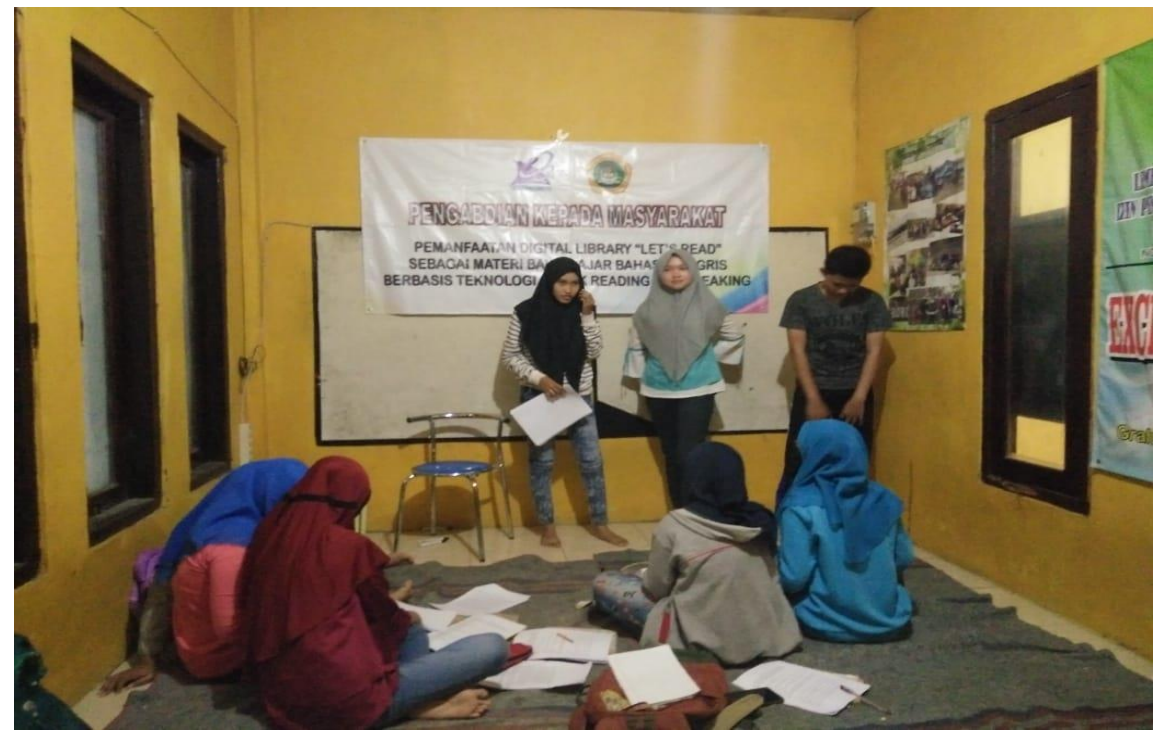

Gambar 6. Siswa mencoba bercerita dengan menggunakan aplikasi Let's Read

\section{KESIMPULAN}

Kesimpulan dari kegiatan ini adalah bahwa penggunaan teknologi itu harus dijadikan sebuah terobosan bagi pengajar dalam kontek belajar dan pembelajaran. Sebisa mungkin, siswa dipaparkan kepada hal-hal yang mereka belum tahu sebelumnya sehingga mereka akan merasa bahwa guru atau tutor sangat kreatif sekali dalam mengajar.

\section{SARAN}

Untuk saran, bacaan yang dipilih oleh siswa harus benar-benar dilihat kembali apakah sudah sesuai dengan tingkatan mereka. Karena hal ini berkaitan dengan penggunaan kosakata yang kadang terlalu sulit sehingga mereka tidak dapat memahami isi cerita sehingga tujuan pembelajaran tidak dapat dicapai.

\section{UCAPAN TERIMAKASIH}

Ucapan terimakasih saya sampaikan kepada YPLP PT PGRI Bangkalan dan Lembaga STKIP PGRI Bangkalan yang telah memberikan bantuan dana hibah Pengabdian kepada Masyarakat ini. Terimakasih juga saya sampaikan kepada segenap pengurus LKP Excellent Course dan seluruh mahasiswa yang telah membantu terlaksananya kegiatan ini. 


\section{DAFTAR PUSTAKA}

Ghasemi, B., \& Hashemi, M. (2011). ICT : Newwave in English language learning / teaching. Procedia - Social and Behavioral Sciences, 15, 3098-3102. https://doi.org/10.1016/j.sbspro.2011.04.252

Iowa State University. (2019). Digital repository. Infotoday.Com, 15(1), 59-91.

Li, S., Jiao, F., Zhang, Y., \& Xu, X. (2019). Problems and Changes in Digital Libraries in the Age of Big Data From the Perspective of User Services. Journal of Academic Librarianship, Vol. 45, pp. 22-30. https://doi.org/10.1016/j.acalib.2018.11.012

Darmawan, Deni. Pendidikan Teknologi Informasi dan Komunikasi, Bandung: RemajaRosdakarya, 2013.

Soetjipto, dkk. Profesi Keguruan. Jakarta: PT Rineka Cipta. 2002 